\title{
On meeting Audre for the first time
}

\author{
Susan Hawthorne
}

\section{Première rencontre avec Audre Lorde}

Tu es sortie des douanes habillée en jaune vif, ton unique sein mis en relief par ton pull serré. Tu as la réputation de confondre toutes les attentes, toi avec ton grand-père marin écossais. Amazonienne aussi ma dernière image de toi, maigre comme une Africaine affamée, souriante comme si tu te fichais du monde avec tant de vitalité que je te croyais victorieuse de ta sœur, la mort.

You walked out of customs in glaring yellow, your

one breast outlined by your tight jumper.

We talked over coffee and afternoon tea, and found a common point: we both had Scottish seafaring grandfathers. This is not what I

had expected. But then you had a reputation for throwing expectations into confusion. And you 
had your arrogances, your misjudgements and an unacknowledged imperialism. In spite

of this I have admired your tenacious vitality.

The last image I have of you is also Amazonian.

Photographs in which you are as thin as a starving

African, your face sharp with pain, your head bare.

And yet, in the midst of that a cheeky defiant smile, a vitality so strong I wondered if you might vanquish sister death. 